\title{
Evaluation of Individual Dependence and Reproducibility of Central Corneal Thickness Measurements with Anterior Segment Optical Coherence Tomography
}

\author{
Ön Segment Optik Koherens Tomografi ile Merkezi Kornea Kalınlığı \\ Ölçümlerinin Bireysel Bağımlılık ve Tekrarlanabilirliğinin Değerlendirilmesi
}

\author{
๑Fatih Çelik, @Pamuk Betül Ulucan Ataş
}

Fethi Sekin City Hospital, Eye Clinic, Elazığ, Turkey

\begin{abstract}
Aim: To compare corneal thickness measurements made at different times and to evaluate their dependence on individuals.

Material and Method: The central corneal thickness(CCT) of the right eyes of 30 healthy young adults was measured by the first investigator at three different times by the Canon HS-100 Anterior Segment Optical Coherence Tomography (AS-OCT) method. In addition, the fourth measurements were made by the second researcher at a different time. The obtained values were compared.

Results: The mean age was 29.8 99.1 years. The mean CCT was $561.90 \pm 37.6 \mu \mathrm{m}$ (micrometer) in the first measurement, $562.20 \pm 37.9 \mu \mathrm{m}$ in the second measurement, and $562.80 \pm 37.7$ $\mu \mathrm{m}$ in the third measurement. In the measurement of CCT by the second investigator, the mean was $562.20 \pm 38.0 \mu \mathrm{m}$. In statistical analysis, no significant difference was found between CCT values performed at different times $(p<0.05)$. In addition, when the first measurement of the first researcher was compared with the first measurement of the second researcher, no significant difference was found between the CCT values of the two researchers $(p<0.05)$.

Conclusion: Canon HS-100 AS-OCT device had very good reproducibility in the evaluation of CCT. There was no significant difference between the shots of different people. The use of OCT in daily practice is beneficial because it is both a non-contact method and has very good reproducibility in daily practice.
\end{abstract}

Keywords: Central corneal thickness, reproducibility, measurement
Öz

Amaç: Farklı zamanlarda yapılan kornea kalınlığı ölçümlerini karşılaştırmak ve kişilere bağımlılığını değerlendirmek.

Gereç ve Yöntem: 30 sağlıklı genç erişkinin sağ gözlerinin santral korneal kalınlığı (SKK) Canon HS-100 Ön Segment Optical Coherence Tomography (ÖS-OCT) yöntemi ile birinci araştırmacı tarafından üç ayrı zamanda ölçüldü. Ayrıca ikinci araştırmacı tarafından dördüncü ölçümleri farklı bir zamanda yapıldı. Elde edilen değerler karşılaştırıldı. Bulgular: Yaş ortalaması 29.8土9.1 idi. Ortalama SKK birinci ölçümde

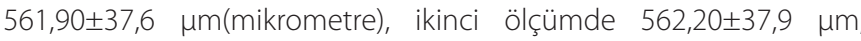
üçüncü ölçümde $562,80 \pm 37,7 \mu m$ idi. SKK'nın 2. araştırmaCı

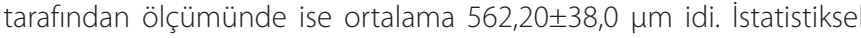
analizde farklı zamanlarda yapılan SKK değerleri arasında anlamlı fark bulunamamıştır $(p<0,05)$. Ayrıca birinci araştırmacının ilk ölçümüyle, ikinci araştırmacının ilk ölçümü karşılaştırıldığında, iki araştırmacı arasındaki SKK değerleri arasında anlamlı fark bulunmadı $(p<0,05)$.

Sonuç: Canon HS-100 ÖS-OCT cihazının SKK değerlendirilmesinde tekrarlanabilirliğinin çok iyi olduğu görüldü. Farklı kişilerin çekimleri arasında anlamlı bir farklılık görülmedi. Günlük pratikte hem nonkontakt bir yöntem olduğu, hem de tekrarlanabilirliği çok iyi olduğu için OCT'nin günlük pratikte kullanılması faydalıdır.

Anahtar Kelimeler: Santral korneal kalınlık, tekrarlanabilirlik, ölçüm 


\section{INTRODUCTION}

The cornea is a transparent, avascular layer located in the anterior part of the eyeball and makes up approximately $1 / 6$ of the entire globe. The area of $2 \mathrm{~mm}$ in the center of the cornea is considered as the central cornea, and the central corneal thickness varies between 0.49 and $0.56 \mathrm{~mm}$, although it shows personal variability. If it is over $0.6 \mathrm{~mm}$, it indicates that the endothelial health is not well. ${ }^{[1]}$ Mean CCT measurement has an important place in the diagnosis of many ophthalmological diseases and especially in followup criteria. ${ }^{[1]}$

It is an extra determining feature in diagnosing ocular hypertension, patient selection and surgical indication in refractive surgery, patient follow-up ${ }^{[2]}$ in keratoconus, determination ${ }^{[3]}$ of corneal edema and in patients with corneal problems such as cornea guttata, as it provides preliminary information about ${ }^{[4]}$ post-op follow-up, especially in cataract surgery.

The fact that CCT is so critical has highlighted the search for non-contact measurement methods in order to eliminate the risk ${ }^{[5,6]}$ of epithelial damage and infection of ultrasound pachymetry, which has been the gold standard for years. Today, non-contact measurement can be made with anterior segment optical coherence tomography (AS-OCT), corneal topography (CT), optical biometry (OB), and specular microscopy (SM) devices. Measurement with AS-OCT, one of these methods, is based on the interference principle. It produces tomographic image sections at the micron level by measuring the reflection delay time and intensity of infrared light of approximately $830-840 \mathrm{~nm}$ wavelength that is sent to the tissues and reflected from different tissues. ${ }^{[7,8]}$

Our aim in this study is to determine the variability of CCT measured with Canon HS-100 AS-OCT in repeated measurements or in measurements made by another researcher and to evaluate its reflection in clinical practice.

\section{MATERIAL AND METHOD}

This study was approved by the Noninterventional Ethics Committee of Firat University on 1 August 2019 with decision number 13; informed consent forms were obtained from the subjects. The right eyes of 30 patients were included in the study. Central corneal thickness values of the patients were measured with the AS-OCT (Canon HS-100, Tokyo, Japan) device. Patients who used contact lenses had a history of corneal pathology or trauma, and had undergone any ocular surgery were excluded from the study. 14 female and 16 male patients were included in the study. The mean age was 29.8 \pm 9.1 for females and 28.4 \pm 7.2 for males (Table 1).

Table 1. Gender distribution and mean ages in the group

\begin{tabular}{lcc} 
& Female & Male \\
\hline Number & 14 & 16 \\
Average age & $29.8 \pm 9.1$ & $28.4 \pm 7.2$ \\
\hline
\end{tabular}

Three measurements were made on the right eyes of the patients with 30 minutes intervals by the same investigator, and a fourth measurement was made by the second observer 1 hour after the third measurement. Statistics: IBM SPSS Statistics Version 22.0 package program was used for statistical analysis of the data. Categorical measurements were expressed as number and percentage, and continuous measurements were expressed as mean and standard deviation (median and minimum-maximum, where necessary). Whether continuous measurements provided the assumption of normal distribution was tested with the Shapiro Wilk test. The Dependent Groups T-test was used to compare dependent continuous measurements. Repeated measures analysis was used to compare the change over time of numerical measurements made on the same individuals at different times. The level of statistical significance was accepted as 0.05 in all tests.

\section{RESULTS}

The mean CCT was $561.90 \pm 37.6 \mu \mathrm{m}$ in the first measurement, $562.20 \pm 37.9 \mu \mathrm{m}$ in the second measurement, and $562.80 \pm 37.7$ $\mu \mathrm{m}$ in the third measurement. In the measurement of CCT by the second researcher, the mean was $562.20 \pm 38.0 \mu \mathrm{m}$ (Table 2).

\begin{tabular}{|c|c|}
\hline & SKK(Micrometer)- Std D. \\
\hline Measurement 1 & $561.90 \pm 37.6 \mu \mathrm{m}$ \\
\hline Measurement 2 & $562.20 \pm 37.9 \mu \mathrm{m}$ \\
\hline Measurement 3 & $562.80 \pm 37.7 \mu \mathrm{m}$ \\
\hline Measurement 4 & $562.20 \pm 38.0 \mu \mathrm{m}$ \\
\hline$\mu \mathrm{m}:$ Micrometer & \\
\hline
\end{tabular}

In statistical analysis, no significant difference was found between CCT values performed at different times $(p<0.05)$. In addition, when the first measurement of the first investigator was compared with the first measurement of the second investigator, there was no significant difference in CCT measurements between the two researchers in the AS-OCT measurements $(p<0.05)$ (Table 3).

\section{Table 3. Comparison of CCT values between groups}

\begin{tabular}{lc} 
& CCT ( $\mathbf{p}$ value) \\
\hline Measurement 1-Measurement 2 & $\mathrm{p}<0.05$ \\
Measurement 1-Measurement 3 & $\mathrm{p}<0.05$ \\
Measurement 2-Measurement 3 & $\mathrm{p}<0.05$ \\
Measurement 1-Measurement 4 & $\mathrm{p}<0.05$ \\
\hline
\end{tabular}

\section{DISCUSSION}

Accurate measurement of central corneal thickness in patients with ocular hypertension is important in predicting the critical importance of post-operative complications in refractive surgery and crosslinking surgeries..$^{[9-11]}$ 
For this reason, it has become important to measure CCT with repetitive measurements and compare the values for the determination of device safety and accuracy. Differences in CCT measurement may result from calibration differences between instruments, as well as from the people who make the measurement or from making measurements on a small number of people. In our study, repeated measurements were made by the same person on the same device. And to determine the possible differences that may occur between individuals, a second researcher was re-measured. In our study, it was aimed to determine the reliability of the Canon HS-100 AS-OCT device and to determine whether there were personal changes in the measurements. According to the statistical analysis of AS-OCT measurements, the repeatability of the Canon HS-100 AS-OCT instrument was very good. The similarity of the measurement made by the second researcher once again confirmed the reliability of the device.

Considering similar studies, Köşker et.al.'s study showed that the device with the strongest reproducibility was OCT among the Combined Scheimpflug-Placido Disc System, Anterior Segment Optical Coherence Tomography, and Corvis Biomechanical Anterior Segment Analysis System. ${ }^{[13]}$ Köşker et al. attributed the best reproducibility of CCT measurements in OCT to the minimization of the effects that may occur due to involuntary eye movement due to high section speed and better detection of corneal borders due to high resolution..$^{[12,13]}$ In other studies, OCT and other non-contact, ultrasonic pachymetry (UP) methods were compared. Leung et al. ${ }^{[14]}$, in their study to compare ultrasonic pachymetry and OCT in the measurement of mean CCT values, found that the measurements made with OCT were approximately $23 \mu \mathrm{m}$ (4\%) higher, although they were correlated with ultrasonic pachymetry.Contrary to this study, Grewal et al. ${ }^{[15]}$ studied patients who had undergone keratoconus and laser in situ keratomileusis surgery and a normal healthy group. They reported that there was a statistically significant difference between the measurements made with Scheimpflug imaging, UP, and OCT, and the measurements made with UP were thicker in all groups.

Fishman et al. ${ }^{[16]}$, on the other hand, did not find CCT values measured by UP and Orbscan topography to be compatible with each other but reported that there was no significant difference between CCT values measured by UP and OCT. They also demonstrated high reproducibility of OCT, which was consistent with our study.

As a result, it is important to have good repeatability of the device so that the clinician can follow the patient more reliably in ophthalmology practice. For this reason, the device should give similar values at different times, even in measurements made by other researchers. In our study, there was no significant difference between the measurements made with the Canon HS-100 AS-OCT device, both at different times and with different people, and the repeatability of the device was shown to be good. For this reason, we think that follow- up with the same device will be more meaningful in terms of treatment and indications, rather than mixing different technical devices in terms of CCT measurement in practical follow-up.

\section{ETHICAL DECLARATIONS}

Ethics Committee Approval: The study was carried out with the permission of Firat University Clinical Research Ethics Committee (Date: 01.08.2019, Decision No: 2019-13/12).

Informed Consent: Because the study was designed retrospectively, no written informed consent form was obtained from patients.

Referee Evaluation Process: Externally peer-reviewed.

Conflict of Interest Statement: The authors have no conflicts of interest to declare.

Financial Disclosure: The authors declared that this study has received no financial support.

Author Contributions: All of the authors declare that they have all participated in the design, execution, and analysis of the paper, and that they have approved the final version.

\section{REFERENCES}

1. Wang Z, Chen J, Yang B. Posterior corneal surface topographic changes after laser in situ keratomileusis are related to residual corneal bed thickness. Ophthalmology 1999;106(2):406-9.

2. Ucakhan OO, Ozkan M, Kanpolat A. Corneal thickness measurements in normal and keratoconic eyes: Pentacam comprehensive eye scanner versus noncontact specular microscopy and ultrasound pachymetry. Journal of cataract and refractive surgery 2006;32(6):970-7.

3. Holden BA, Mertz GW, McNally JJ. Corneal swelling response to contact lenses worn under extended wear conditions. Investigative ophthalmology \& visual science 1983;24(2):218-26.

4. Auffarth GU, Wang L, Volcker HE. Keratoconus evaluation using the Orbscan Topography System. Journal of cataract and refractive surgery 2000;26(2):222-8.

5. Barkana Y, Gerber Y, Elbaz U, et al. Central corneal thickness measurement with the Pentacam Scheimpflug system, optical low-coherence reflectometry pachymeter, and ultrasound pachymetry. J Cataract Refract Surg 2005;31(9):1729-35.

6. Swarbrick HA, Wong G, O'Leary DJ. Corneal response to orthokeratology. Optom Vis Sci. 1998;75(11):791-9.

7. Kawana K, Tokunaga T, Miyata K, Okamoto F, Kiuchi T, Oshika T. Comparison of corneal thickness measurements using Orbscan II, noncontact specular microscopy, and ultrasonic pachymetry in eyes after laser in situ keratomileusis. Br J Ophthalmol 2004;88(4):466-8.

8. Piotrowiak I, Soldanska B, Burduk M, Kaluzny BJ, Kaluzny J. Measuring Corneal Thickness with SOCT, the Scheimpflug System, and Ultrasound Pachymetry. ISRN Ophthalmol 2012;2012:869319.

9. Coskunseven E, Jankov MR, 2nd, Hafezi F. Contralateral eye study of corneal collagen cross-linking with riboflavin and UVA irradiation in patients with keratoconus. Journal of refractive surgery (Thorofare, NJ : 1995) 2009;25(4):371-6.

10. Muallem MS, Yoo SH, Romano AC, Marangon FB, Schiffman JC, Culbertson WW. Flap and stromal bed thickness in laser in situ keratomileusis enhancement. J Cataract Refract Surg 2004;30(11):2295-302.

11. Randleman JB, Woodward M, Lynn MJ, Stulting RD. Risk assessment for ectasia after corneal refractive surgery. Ophthalmology 2008;115(1):3750. 
12. Kosker M, Calıskan S, Celikay O, Dogan AS, Kaya A, Gurdal C. Assesment of Central Corneal Thickness Using Corneal Dynamic Scheimpflug Analyzer Corvis ST, Sirius Kombine Scheimpflug-Placido Disk System and RTVue Anterior Segment Optical Coherence Tomography in Normal Eyes. Van Med J 2018;25(3):381-385.

13. Li $Y$, Tang $M$, Zhang $X$, Salaroli $C H$, Ramos JL, Huang D. Pachymetric mapping with Fourier-domain optical coherence tomography. J Cataract Refract Surg 2010;36(5):826-31.

14. Leung DY, Lam DK, Yeung BY, Lam DS. Comparison between central corneal thickness measurements by ultrasound pachymetry and optical coherence tomography. Clin Exper Ophthalmol 2006;34(8):751-4.

15. Grewal DS, Brar GS, Grewal SP. Assessment of central corneal thickness in normal, keratoconus, and post-laser in situ keratomileusis eyes using Scheimpflug imaging, spectral domain optical coherence tomography, and ultrasound pachymetry. J Cataract Refract Surg 2010;36(6):954-64.

16. Fishman GR, Pons ME, Seedor JA, Liebmann JM, Ritch R. Assessment of central corneal thickness using optical coherence tomography. J Cataract Refract Surg 2005;31(4):707-11. 